\title{
Histology and Histochemistry of Mantle of Lymnaea Luteola (Lamarck 1799) Mollusca Gastropoda
}

\author{
Vijaya Kumar $\mathrm{K}^{1}$, Priyadarsini $A \mathrm{~S}^{2}$ \\ ${ }^{I}$ Department of Zoology, Andhra University, Visakhapatnam, AP - India \\ ${ }^{2}$ Department of Zoology, St. Joseph's College for Women (A), Gnanapuram, Visakhapatnam, AP - India
}

\begin{abstract}
The mantle is an important molluscan organ. It serves as a respiratory organ in most of the pulmonates; its walls have a dense vascular network. It is an outer jacket of the visceral mass and harbors the pulmonary chamber on its right side. Mantle is the specialized organ of the gastropods for it not only bears the glands that secrete the shell but also acts as buffer between the hard calcareous shell and the animal itself, spreading like a cushion through the entire inner surface of the body whorl. In Lymnaea luteola two types of gland cells are noticed in the mantle;epithelia and sub - epithelial. The epithelial mucous glands secrete metachromatic, alcianophilic sulphated mucopolysaccharides. The sub-epithelial mucous glands are classified into two categories, according to their histochemical reactions. Some of them secrete non-metachromatic, alcianophilic sulphated mucopolysaccharides and others secrete mucosubstances which are carboxylated.
\end{abstract}

Keywords: Histology, histochemistry, mantle, Lymnaea luteola, mucocytes

\section{Introduction}

Our knowledge of the histology of the mantle dates back to 1846 when, Meckel made some preliminary observations on the mantle of Helix. The glandular nature of the mantle, epidermis was described by Kuttler (1913) in Oliva; Frank (1914) found the same in trichoids. Burkhardt (1916) made investigations on the mantle margin of Helix pomatia. Information on the histochemical nature of the glands of the mantle of Helix pomatia was furnished by Guardabassi and Piacenz (1958). Gostan (1960) reported the presence of acid mucopolysaccharides in the mantle of Rissoa parva. Zylstra et al. (1979) dealt with the ultra structure, histology and innervations of the mantle edge of the freshwater pulmonate snails Lymanaea stagnalis and Biomphalaria pfeifferi. Roula Jabbour -Zahab et al (1992); give information on the mantle histology, histochemistry and ultra structure of the pearl oyster Pinctada margaritifera (L.). Lee et al, 2007; investigated the Histology and ultra structure of the mantle epidermis of the equilateral Venus, Gomphin veneriformis (Bivalvia: Veneridae). However, the nature of gland cells in the mantle of Lymnaea luteola (Lamarck) has not been studied. A comparison of the mantle organization and the nature of gland cells of this species, with that of other univalves are thus necessary. Hence in the present investigation the nature of mucopolysaccharides in Lymnaea luteola and their distribution and function have been studied.

\section{Material And Methods}

Lymnaea luteola is a fresh water snail commonly found in freshwater ponds, lakes and pools. The most commonly present species in Andhra Pradesh are Lymnaea luteola and Lymnaea acuminata. Among these, Lymnaea luteola are found abundantly in surrounding areas of Visakhapatnam freshwater bodies and Lymnaea acuminata are scarcely seen. For the study, L. luteola has been selected. Specimens were collected from Kondakarla Lake situated at a distance of $50 \mathrm{~km}$. from Visakhapatnam. Lymnaeides were collected twice a week. For general morphology the shell is removed carefully with the help of a needle and forceps and was studied under stereo dissection microscope. For histological and histochemical studies, material was fixed in Susa, alcoholic Bouin's and Zenker's fixatives and processed. By using Microtome the material was sectioned transversely and sagittal ranging from 7-10 $\mu$ and the sections obtained were stained after 2 or 3 days in various stains for histological and histochemical studies. Heidenhain's Azan and Mallory's triple stains were used for histological investigations. All histochemical procedures are adopted from Pearse (1968) (Table.- I).

\subsection{Histology}

\section{Results}

The mantle cavity and its associated organs together with buccal mass and the radula are basic molluscan features. The mantle cavity occupies an anterior position and both the gut and the nervous systems are twisted. In Lymnaea, mantle is the projecting fold of the body wall that lines the body whorl of the shell. The mantle cavity is thin and bound by a single layer of epithelial cells. The mantle cavity is thin and bound by a single layer of epithelium on both sides facing the shell which is known as the outer epithelium and that facing the mantle cavity is known as the inner epithelium (Fig.1\&2). Various sub-epidermal gland cells are present in 
the mantle. They are nearly always associated with the inner epithelium or the mantle edge and not with the outer epithelium. Outer mantle epithelium is thin when compared with inner epithelium and measures about $10 \mu$ in height. Mucocytes are scanty, interspersed here and there along the epithelial cells. Well developed muscle bundles are present. The inner epithelium has long ciliated cells. Mucocytes are many, at the ratio of one for every three columnar epithelial cells. They are club-shaped and granular.

\subsection{Histochemistry}

A series of histochemical techniques have been applied to know the chemical nature of the different types of glands present in the mantle. The glands in the mantle are PAS positive and this reaction was abolished after acetylation and restored after deacetylation indicating the presence of 1:2 glycol groups. The epidermal cells give a positive reaction to alcian blue at both $\mathrm{pH} 1.0$ and 2.5 suggesting presence of both sulphated and carboxylated mucopolysaccharides. Most of the glands in mantle are blue with the combined technique of $\mathrm{AB}$ ( $\mathrm{pH}$ 1.0) / PAS and AB ( $\mathrm{pH} 2.5$ ) /PAS (Fig.3\&4). It shows the presence of neutral mucopolysaccharides and sialomucins in the former and sulphated mucopolysaccharides in the latter. When the PAS stained sections are counter stained with light green, cells of the shell gland stained green showing the presence of protein, while the epidermal cells stained magenta. With AF/AB technique, the epidermal gland cells stained purple, showing the presence of sulfated mucosubstances. Remaining glands stained weakly to moderately, indicating the presence of non-sulfated mucosubstances. In the epidermal mucocytes, the absence of glycoproteins, basic proteins, tryptophan, tyrosine and sulfhydryl groups was shown by their negative reaction to Congo red, Mercury, Bromophenol Blue, P-DMAB-nitrite, Millon's reaction and Ferricferricyanide respectively. With Schiff's technique, these glands stained dark magenta showing the presence of protein bound amino groups. The presence of disulphide group is shown by their fairly positive response to $\mathrm{KMno}_{4} / \mathrm{AB}$.

Results of the above histochemical techniques presented in the table - I

Table -I

\begin{tabular}{|c|l|c|l|}
\hline S.No. & \multicolumn{1}{|c|}{ Histochemical tests applied } & Results & \multicolumn{1}{|c|}{ Remarks } \\
\hline 1. & Alcian Blue pH 1.0 (AB) & $\begin{array}{c}+++ \\
\text { Blue }\end{array}$ & $\begin{array}{l}\text { Sulphated weakly acidic } \\
\text { mucopolysaccharides }\end{array}$ \\
\hline 2. & Alcian Blue pH 2.5 (AB) & $\begin{array}{c}+++ \\
\text { Greenish } \\
\text { blue }\end{array}$ & Strongly acidic non sulphated \\
\hline 3. & Alcian Blue pH 2.5 (AB) / PAS & +++ & Red - neutral blue-sulphated \\
\hline 4. & Alcian Blue pH 1.0 (AB) / PAS & ++ & $\begin{array}{l}\text { Blue-sulphated } \\
\text { Red-sialomucins }\end{array}$ \\
\hline 5. & Periodic acid / Schiff's (PAS) & +++ & Carbohydrates \\
\hline 6. & Acetylation / PAS & - & $1: 2$ glycols abolished \\
\hline 7. & Deacetylation / PAS & ++ & $1: 2$ glycols restored \\
\hline 8. & Aldehyde Fuchsin (AF) & ++ & Purple-both weakly \& strongly acid mucosubstances \\
\hline 9. & Aldehyde Fuchsin /Alcian Blue (AF/AB) & + & Spares proteins \\
\hline 10. & Bromophenol blue & strongly acidic purple - non sulphated \\
\hline
\end{tabular}

$+++=$ Strongly positive; $\quad++=$ moderately positive

$+\quad=$ Positive; $\quad-=$ Negative

\section{Discussion}

In all mollucs, the mantle is directly responsible for shell synthesis. The mantle of bivalves and gastropods are involved in purification of the mantle cavity and shell formation through mucous secretion. Purification of the mantle cavity is accomplished by the inner epidermis, whereas the shell formed by the outer epidermis. In Lymnaea luteola the mantle has the same arrangement of muscles and connective tissue of molluscan plan. The dorsal and ventral epithelia have muscle fibers and strands of connective tissue between. In Pinctada mazatianica the marginal zone of the mantle is divided into the inner fold, middle fold and outer fold. Among these folds the inner fold is the largest in its size, and the outer fold is the smallest (Garcia - Gasca et. al 1994). The inner epithelium of Lymnaea luteola is richly provided with mucocytes and is devoid of epidermal glands. Similar epidermal gland cells were described previously by Seshaiya (1934) in Paludomus. The presence of gland cells in the ventral surface of the mantle is reported by Frank (1914) in the trichid Monodonta, Kuttler (1913) in Uliva and Neumann (1928) in Viviparous. The presence of epidermal goblet cells bring up an interesting point in view of the assertion by Herfs (1922) and Hyman (1967) that all gland cells associated with the epidermis in freshwater gastropods are of the sub - epidermal type. Zylstra (1972) described a single type of epidermal goblet cell in the ventral epidermis of Lymnaea stagnalis.

The mantle edge, apart from its shell secreting function has important glandular, sensory activities and is an important area of growth and secretion. Large gland clusters open into the dorsal margin. The dorsal clusters which open on the dorsal side of the mantle edge is of common occurrence in prosobranches such as 
Buccinum (Dakin, 1912), Viviparous (Annandale, 1952). The characteristics of mucous secreted by the gland cells, a group of cells that compose the mantle epithelial layer, are reported to differ slightly from species to species and in the mantle zone. Although the chemical composition of mucous substances generated in the mantle varies greatly, they are composed mainly of mucopolysaccharides, glycoproteins and carbohydrates (Prezant 1981). Secretary cells, a type of typical mucous cell, play an important role in shell formation in Mercenaria mercenaria (Hillman 1968) and Helisoma duryi eudiscus (Kapur \& Gibson, 1968).

In the case of Lymnaea stagnalis (Timmermans 1969) mucous substances secreted contribute to lubrication action of the mantle. Gracia - Gasca et.al (1994) reported four types of secretory cells in the mantle epidermis of pearl oyster, Pinctada mazatianica. Secretory cells in the outer epidermis contain neutral sulphated mucosubstance. However, secretory cells in the outer epidermis contain acidic sulphated mucopolysaccharides and carboxylated mucopolysaccharides (Lee 2002).

\section{References}

[1]. Annandale, T.N., and Rao, H.S., 1925. Materials for a revision of the recent Indian Limnaeidae (Mollusca, Pulmonata).- Records of the Indian Museum, Calcutta, t. 27, pp. 137-189, 15 fig.

[2]. Dakin, W.J., 1912. 'Buccinum (the whelk)' L.M.B.C. Mem. type. Br.mar. Pl. Anim., 20: 1-115.

[3]. Frank, E.J., 1914. Beitrage zur Anatomie der Trochiden (Monodonta turbinate, Gibbus cinerea, Photinula taeniata). Jena. Z. naturw. 51: $377-486$

[4]. Garcia - Gasca, A., R.I. Ochoa - Baez and Betancourt, M., 1994. Microscopic anatomy of the pearl oyster Pinctada mazatlanica (Hanley, 1856). J. Shellfish Res. 13:85-91.

[5]. Gostan, G., 1960. Repartition des polysaccaharides chez Rissoa. Bull. Soc. Zool. Fr. 85

[6]. Guardabassi, A. and Piacenza, M., 1958. Le manteau de L' escargot Helix pomatia, etude cytologigue et histochemique. Arch. Anat. Microcs. Morphol. Expt., 47.

[7]. Herfs, A., 1922. Studien an den Hautdrusen der Land - und Susswasser - gastropoden. Archiv. mikrosc. Anat., 96 : 1- 38.

[8]. Hillman, R.E., 1968. Histochemistry of mucosubstances in the mantle of the clam Mercenaria mercenaria 1: A glycosaminoglycan in the first marginal fold. Trans. Am. micros. Soc., 87: 361-367.

[9]. Hyman, L.H., 1967. The Invertebrates. Mollusca I. McGraw-Hill Book Company, New York.

[10]. Kapur, S.P. and Gibson, M.A., 1968. A histochemical study of the development of mantle edge and shell in the freshwater gastropod Helisoma duryi eudiscus (Pilsbry). Can. J. Zool., 46 (3) : 481 - 491.

[11]. Kuttler, A., 1913. Die Anatomie von Oliva peruviana Lamarck. Zool. Jb. (Suppl.) 13 (Fauna Chilensis), 477 -544.

[12]. Lee, J. S. 2002. Ultra structure of the mantle epidermis in the ark shell Scapharca broughtonii (Bivalvia: Arcidae). Korean J. Electron Microscopy 32: 213-222.

[13]. Lee., Jung Sick., Joo., Ja Young, Park., Jung Jun., 2007. Histology and ultrastructure of the mantle epidermis of the Venus, Gomphina veneriformis (Bivalvia: Veneridae). Journal of Shellfish Research.

[14]. Meckel, H., 1846. Mikrographie einiger Drusenapparate der niederen in Pila virens (L). J. Anim. Morph. Physiol., 1: 35 -47.

[15]. Neumann, G., 1928. Mantelorgane und Mantelbrandes von Paludina. Jena. Z. naturw. 63.

[16]. Pearse, A,G.E., 1968. Histochemistry: Theoretical and applied. $3^{\text {rd }}$ edition. J.A. Churhill, London, Vol. I. 1518 pp.

[17]. Prezant, R.S., 1981. The arenophilic radial mantle glands of the lyonsiid evolution. Malacologia. 20: $267-289$

[18]. Roula Jabbour-Zahab R., D. Chagot, F. Blanc, H. Grizel., 1992. Mantle histology, histochemistry and ultra structure of the pearl oyster Pinctada margaritifera (L.). Aquat. Living Resour. 5, 287-298.

[19]. Seshaiya, R.V., 1934. Anatomy of Paludomus tenschaurica (Gmelin). Ibid., 36: 185 -212.

[20]. Timmermanas, L.P.M., 1969. Studies on shell formation in Mollusca. Neth. J. Zool., 19: 417-523.

[21]. Zylstra, U., 1972. Histochemistry and ultra structure of the epidermis and the subepidermal gland cells of the freshwater snails Lymnaea stagnalis and Biomphalaria pfeifferi. Z. Zellforsch. Mikrosk. Anat., 130: 93 - 134.

[22]. Zylstra, U., Boer, H.H. and Sminia, T., 1979. Ultra structure, histology and innervations of the mantle edge of the freshwater pulmonate snails Lymnaea stagnalis and Biomphalaria pfeifferi. Calcif. Tissue Res., 26(3) : 271-282.

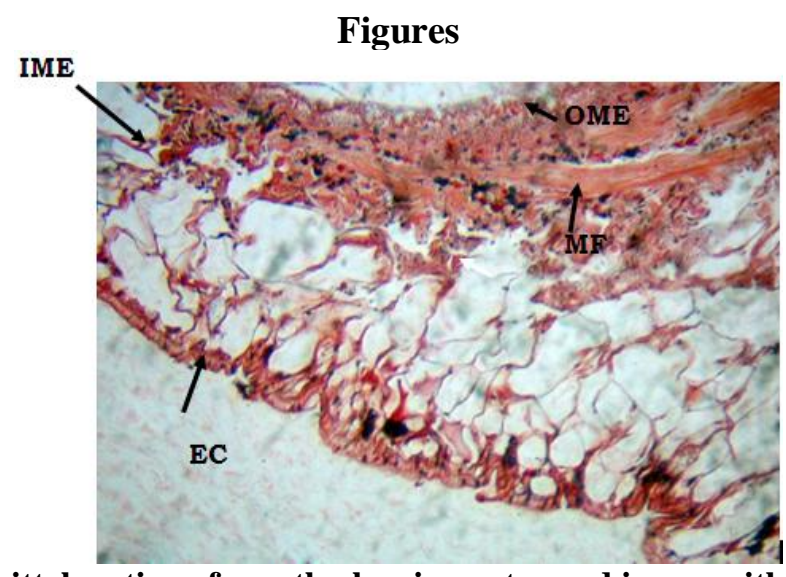

Fig.1. Sagittal section of mantle showing outer and inner epithelium and Muscle fibers showed with Azan 


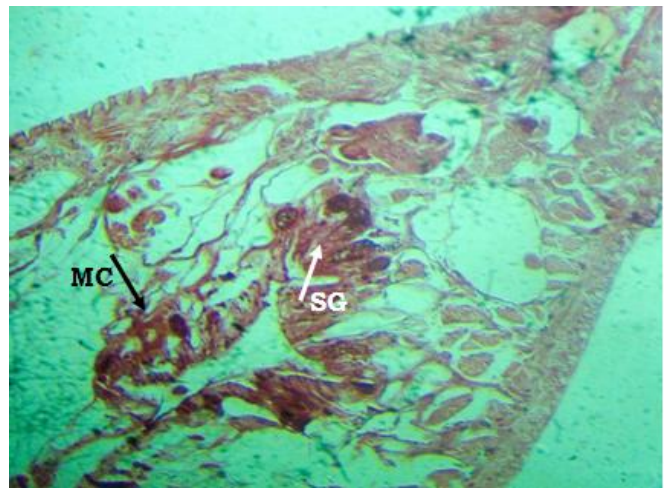

Fig.2. Enlarged view of mantle showing mucocytes, shell gland, and epithelial cells stained with Azan

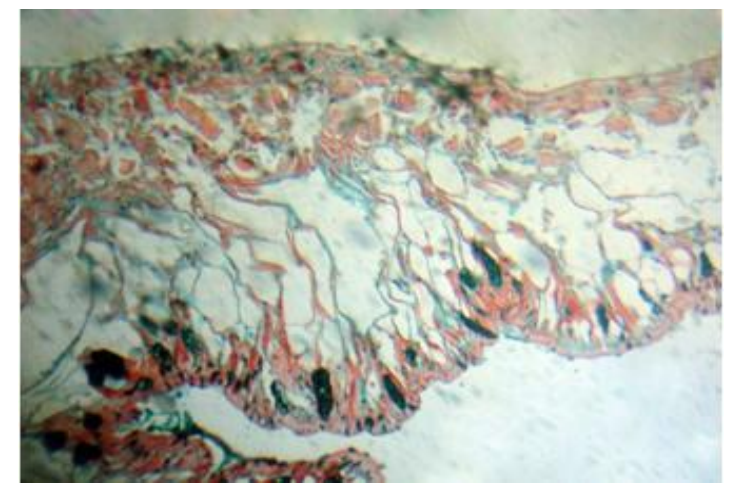

Fig. 3. Sagittal section of mantle showing to shell gland, epithelial cells and gland cells indicating the presence of neutral mucopolysaccharides, sialomucins and sulfated mucopolysaccharides. Alcian Blue / Periodic Acid Schiffs's Reagent (AB/PAS).

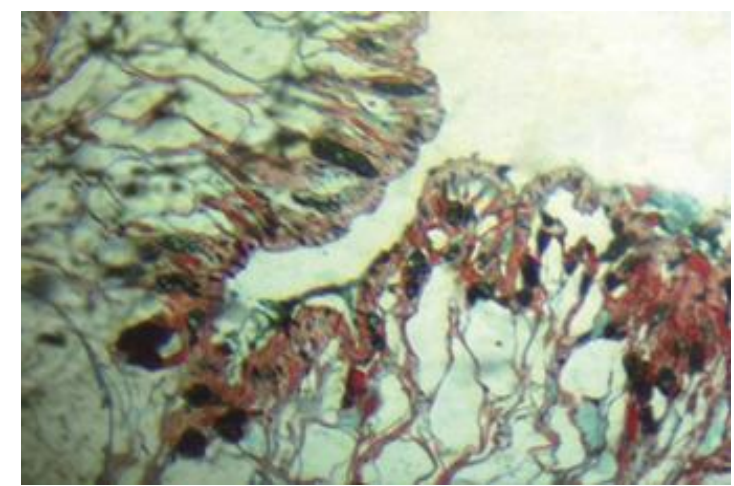

Fig. 4. Shell gland in enlarged view (AB/PAS)

\section{Key to Lettering}

EC -Epithelial Cells

GC - Gland Cells

MC - Mucocytes

MF - Muscle Fibers

PG - Pedal Glands

OME -Outer Mantle Epithelium

IME -Inner Mantle Ep:thelium 